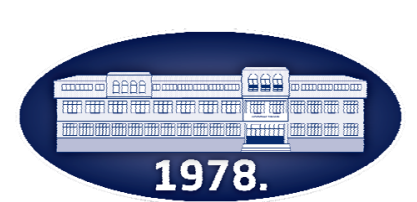

Publisher: Faculty of Agronomy Čačak

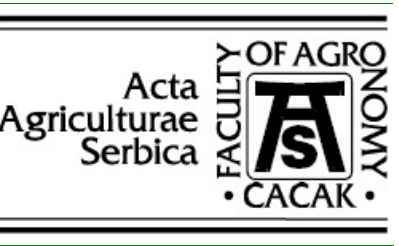

\title{
Effect of biostimulants on soybean seedlings
}

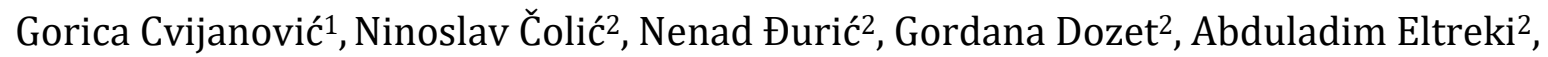 \\ Marija Cvijanovićs ${ }^{3}$, Milena Žuža ${ }^{2}$
}

${ }^{1}$ University of Kragujevac, Institute for Information Technologies Jovana Cvijića bb, Kragujevac, Serbia

2Megatrend University, Faculty of Biofarming Maršala Tita 39, 24300 Bačka Topola, Serbia

${ }^{3}$ University of Bijeljina, Faculty of Agriculture Pavlovića put bb, 76300 Bijeljina, BiH

*Corresponding author: cvijagor@yahoo.com

Received 8 April 2020; Accepted 9 September 2020

\begin{abstract}
A B S T R A C T
The aim of this study was to analyze the effect of biostimulants on the morphological characteristics of soybean seedlings. The testing was conducted in the laboratory of the Faculty of Biofarming in Bačka Topola. The experimental material included three soybean varieties ('Galina', 'Sava' and 'Rubin') selected at the Institute of Field and Vegetable Crops in Novi Sad. The study lasted for two years, 2015-2016, and identical biostimulant treatments were applied in both years. In order to determine the effect of biostimulants on soybean seedling root, hypocotyl and weight, the following commercial biostimulants were applied: EM Aktiv, Terra Green Hobby, Slavol and Bioplant Flora. In addition to the single application of biostimulants, two combinations of Slavol + Bioplant Flora and Slavol + Bioplant Flora + Epin Extra + Slavol S were used as treatments. EM Aktiv showed the greatest effect on root growth. The root was on average $12 \%$ longer than the control. Slavol S had the greatest influence on seedling hypocotyl and weight. The increase was $8.24 \%$ and $5.15 \%$, respectively, compared with the control.
\end{abstract}

Keywords: biostimulants, seedlings, soybean, varieties.

\section{И 3 В О д}

Циљ рада био је да се испита деловање биостимулатори на морфолошке особине клијанца соје. Тестирање је спроведено у лабораторији Факултета за биофарминг у Бачкој Тополи. Експериментални материјал су биле три сорте соје (Галина, Сава и Рубин) селекционисане на Институту за ратарство и повртарство у Новом Саду. Истраживање је трајало две године, 2015-2016, и у обе године примењени су идентични третмани са биостимулаторима. У сврху утврђивања утицаја биостимулатора на дужину корена, дужину надземног дела и масу клијанца соје примењени су различити комерцијални биостимулатори под називом: EM Aktiv, Terra Green Hobby, Slavol и Bioplant Flora. Поред појединачне примене биостимулатора, као третмани коришћене су и две комбинације Slavol + Bioplant Flora и Slavol + Bioplant Flora + Epin Extra + Slavol S. Резултати истраживања су показали да примена адекватног биостимулатора утиче позитивно на морфолошке особине клијанца соје, док неадекватна комбинација биостимулатора доводи до инхибиторног деловања. EM Aktiv је показао највећи ефекат на раст корена. Корен је у просеку био 12\% дужи од контроле. Slavol S je показао највећи утицај на хипокотил и тежину садница. Повећање је било 8,24\% и 5,15\% у поређењу са контролом.

Кључне речи: биостимулатори, клијанци, соја, сорте.

\section{Introduction}

Soybean (Glycine max (L.) Merr.) is a major crop, not only in agricultural production but also in industrial processing. It ranks fourth in terms of production area in the world (Balesević and Miladinović, 2014). Worldwide, it is grown on an area of about 123.5 million hectares (http://faostat.fao.org, 2017). Using high quality seeds is a basic factor that determines high crop yields (Milošević et al., 1996). However, since soybeans are sown in different agroecological conditions, seed germination and vigor are influenced by various adverse environmental factors such as drought and extreme temperatures (Casenave and Toselli, 2007). Therefore, different methods are used to reduce the negative impact of environmental factors (Djukić et al., 2017; Miladinov et al., 2019). Biostimulants can be used to improve seed quality
(Yildirim et al., 2007). Biostimulants are neither plant nutrients nor pesticides; they are organic materials that, when used in small amounts, improve plant growth and development, but to a degree different from the use of traditional plant nutrients (Yakhin et al., 2017).

Biostimulants can be divided into humic acidcontaining biostimulants, hormone-containing biostimulants and amino acid-containing biostimulants, or biostimulants of plant growth and development depending on the type of biostimulant (Tkalec, 2010). Also, biostimulants must be able to penetrate the plant tissue. This is of great importance, especially in field conditions, where treated plants are exposed to different agroenvironmental conditions (Kolomazik et al., 2012). However, in addition to their positive effect on seed germination, biostimulants in some cases have the ability to reduce seed quality (Miladinov et al., 
2014a) as well as to inhibit seedling growth (Miladinov et al., 2015).

There has not been much research on the effect of biostimulants on seedlings. Therefore, the aim of this paper was to investigate the influence of different biostimulants and their combinations on the morphological parameters of soybean seedlings.

\section{Material and Methods}

The research was carried out in the laboratory of the Faculty of Biofarming in Bačka Topola. Testing was performed on seeds of three soybean varieties: 'Galina', 'Sava' and 'Rubin' (Factor A). The varieties were selected at the Institute of Field and Vegetable Crops in Novi Sad, and research was conducted during 2015 and 2016 (Factor C). The seeds were treated with solutions of the following biostimulants (Factor B):

\begin{tabular}{|c|c|c|}
\hline $\begin{array}{l}\text { Treatment and } \\
\text { concentration }\end{array}$ & Abbreviation & Active substance \\
\hline $\begin{array}{c}\text { EM Aktiv } \\
(50 \%)\end{array}$ & EM & $\begin{array}{c}\text { lactic acid bacteria, photosynthetic bacteria, ferment, cane } \\
\text { molasses }\end{array}$ \\
\hline $\begin{array}{l}\text { Terra Green Hobby } \\
(100 \%)\end{array}$ & FT & $\begin{array}{c}\text { lactic acid bacteria, photosynthetic bacteria, ferment, cane } \\
\text { molasses }\end{array}$ \\
\hline $\begin{array}{c}\text { Bioplant Flora } \\
(2 \%)\end{array}$ & B & $\begin{array}{c}\text { humic acids, fulvo acids, amino acids, phytohormones, macro } \\
\text { and micro elements, } \mathrm{N}, \mathrm{K}_{2} \mathrm{O}\end{array}$ \\
\hline $\begin{array}{c}\text { Slavol S } \\
(33 \%)\end{array}$ & S & indole-3-acetic acid \\
\hline $\begin{array}{c}\text { Slavol S }(20 \%)+ \\
\text { Bioplant Flora }(2 \%) \\
\end{array}$ & $\mathrm{S}+\mathrm{B}$ & $\begin{array}{c}\text { indole-3-acetic acid + humic acids, fulvo acids, amino acids, } \\
\text { phytohormones, macro and micro elements, } \mathrm{N}, \mathrm{K}_{2} \mathrm{O}\end{array}$ \\
\hline $\begin{array}{l}\text { Slavol S }(20 \%) \\
+ \text { Bioplant }(2 \%)+\text { Epin } \\
\text { Ekstra }(0.05 \%)+\text { Slavol } \\
\text { for soybean }(10 \%)\end{array}$ & $\mathrm{S}+\mathrm{B}+\mathrm{E}+\mathrm{SS}$ & $\begin{array}{l}\text { indole-3-acetic acid + humic acids, fulvo acids, amino acids, } \\
\text { phytohormones, macro and micro elements, } \mathrm{N}, \mathrm{K}_{2} \mathrm{O}+\text { auxins, } \\
\text { cytokinins, gibberellins, ethylene and abscisic acid + symbiotic } \\
\text { bacteria, associative and phosphorus mineralizing bacteria }\end{array}$ \\
\hline
\end{tabular}

The seeds treated with distilled water (C) were used as controls.

During the preparation of the solutions, given the negative effect of light on biostimulants containing active microorganisms, the whole process (from dosage to treatment of the seed and its comparison with the substrate) took place in a slightly darkened part (away from the light source) of the laboratory. The seeds were sprayed with biostimulant solutions. After 30 minutes, the seeds were spread on filter paper. They were evenly applied to filter paper measuring 580 x $580 \mathrm{~mm}$ (58 cm in length), and $580 \times 290 \mathrm{~mm}$ (Factor D). Seed germination was performed under laboratory conditions using a standard laboratory test. Standard laboratory germination was tested for $4 \times 100$ seeds. The incubation period was eight days at $25^{\circ} \mathrm{C}$ and $95 \%$ relative humidity (ISTA, 2008). After eight days of incubation, $4 \times 10$ average fresh soybean seedlings were taken from each treatment for the analysis of seedling root, hypocotyl, and weight.

The statistical significance of differences between treatment means was tested by four-way ANOVA with LSD test at two levels of significance (5\% and $1 \%$ ). Pearson's correlations between the tested properties were assessed for significance by the t-test.

\section{Results and Discussion}

The analysis of the effect of variety (A), treatment (B), year (C) and type of filter paper (D) on soybean seedlings showed that these factors had a very significant effect on root growth. All factors except year significantly influenced the hypocotyl growth and weight of seedlings (Table 1). Also, for all parameters, a very significant interaction was established between the factors, $\mathrm{AxB}, \mathrm{AxD}, \mathrm{AxBxC}$ and $\mathrm{AxBxCxD}$.

Table1.

Effect of the factors under consideration on the parameters examined

\begin{tabular}{|c|c|c|c|}
\hline Factors & $\begin{array}{l}\text { Seedling } \\
\text { root }\end{array}$ & $\begin{array}{l}\text { Seedling } \\
\text { hypocotyl }\end{array}$ & $\begin{array}{c}\text { Seedling } \\
\text { weight }\end{array}$ \\
\hline Variety (A) & $* *$ & $* *$ & $* *$ \\
\hline Biostimulants (B) & $* *$ & $* *$ & $* *$ \\
\hline Year (C) & $* *$ & ns & ns \\
\hline Length of filter paper (D) & $* *$ & $* *$ & $*$ \\
\hline $\mathrm{AxB}$ & $* *$ & $* *$ & $* *$ \\
\hline $\mathrm{AxC}$ & $*$ & $*$ & ns \\
\hline AxD & $* *$ & $* *$ & $* *$ \\
\hline $\mathrm{BxC}$ & $* *$ & $*$ & ns \\
\hline BxD & ns & $* *$ & $*$ \\
\hline $\mathrm{CxD}$ & $* *$ & ns & $*$ \\
\hline $\mathrm{AxBxC}$ & $* *$ & $* *$ & $* *$ \\
\hline $\mathrm{AxBxD}$ & $* *$ & $* *$ & $* *$ \\
\hline $\mathrm{AxCxD}$ & $* *$ & $* *$ & ns \\
\hline $\mathrm{BxCxD}$ & $* *$ & $* *$ & $*$ \\
\hline $\mathrm{AxBxCxD}$ & $* *$ & $* *$ & $* *$ \\
\hline
\end{tabular}

** - significant at $0.01 ;^{*}$ - significant at $0.05 ; \mathrm{ns}$ - not significant 
The results of this study are in agreement with the research conducted by Vernieri et al. (2006) and Parađiković et al. (2008), who pointed out that the application of biostimulants in the germination stage can establish better conditions for the growth and development of seedlings, and especially the roots. Positive effects of biostimulants have been determined in the production of seedlings of vegetables, flowers, and medicinal, aromatic and spicy herbs (Jelačić et al., 2006; Gajc-Wolska et al., 2012; Zeljković et al., 2013; Palfi et al., 2017). However, in addition to having a positive effect, biostimulants can also have a negative effect on the seed if used at high concentrations (Türkmen et al., 2004) or due to an improper combination of incompatible biostimulants (Miladinov et al., 2014b).

\section{Effect of biostimulants on soybean seedling root growth}

The results showed that the application of a regulator can have a positive effect on soybean seedling root growth. The greatest effect is achieved by EM Activ treatment. Eight days after seed treatment, soybean seedlings had significantly longer roots relative to other treatments and controls. Root length averaged $15.5 \mathrm{~cm}$, which is $12 \%$ longer than the control. Effective microorganisms found in EM Activ, in addition to nitrogen fixation and mineralization of organic forms of phosphorus in the soil, synthesize active substances such as enzymes, amino acids, vitamins, and fungicidal substances, thus directly or indirectly affecting the growth and development of plants (Cvijanović, 2017). Szymanski et al. (2003) reported that EM Activ led to an increase in seed germination and root development, enhanced flowering and fruit formation, and improved soil fertility. EM Activ was also found to have a positive effect on soybean yield. In two-year studies, the yield increased by an average of $10.84 \%$ i.e. by $6.86 \%$ and $14.81 \%$ per year, respectively (Dozet et al., 2014). The effect of the other treatments on root growth was not significant, but they gave longer roots than the control. Compared with the control, Slavol S promoted root elongation by $7.27 \%$, Terra Green Hobby by $6.77 \%, \mathrm{~S}+$ B + E + SS by $5.61 \%$, and Bioplant Flora by $5.28 \%$, whereas the combination of $\mathrm{S}+\mathrm{B}$ increased root length by $4.82 \%$ (Figure 1 ).

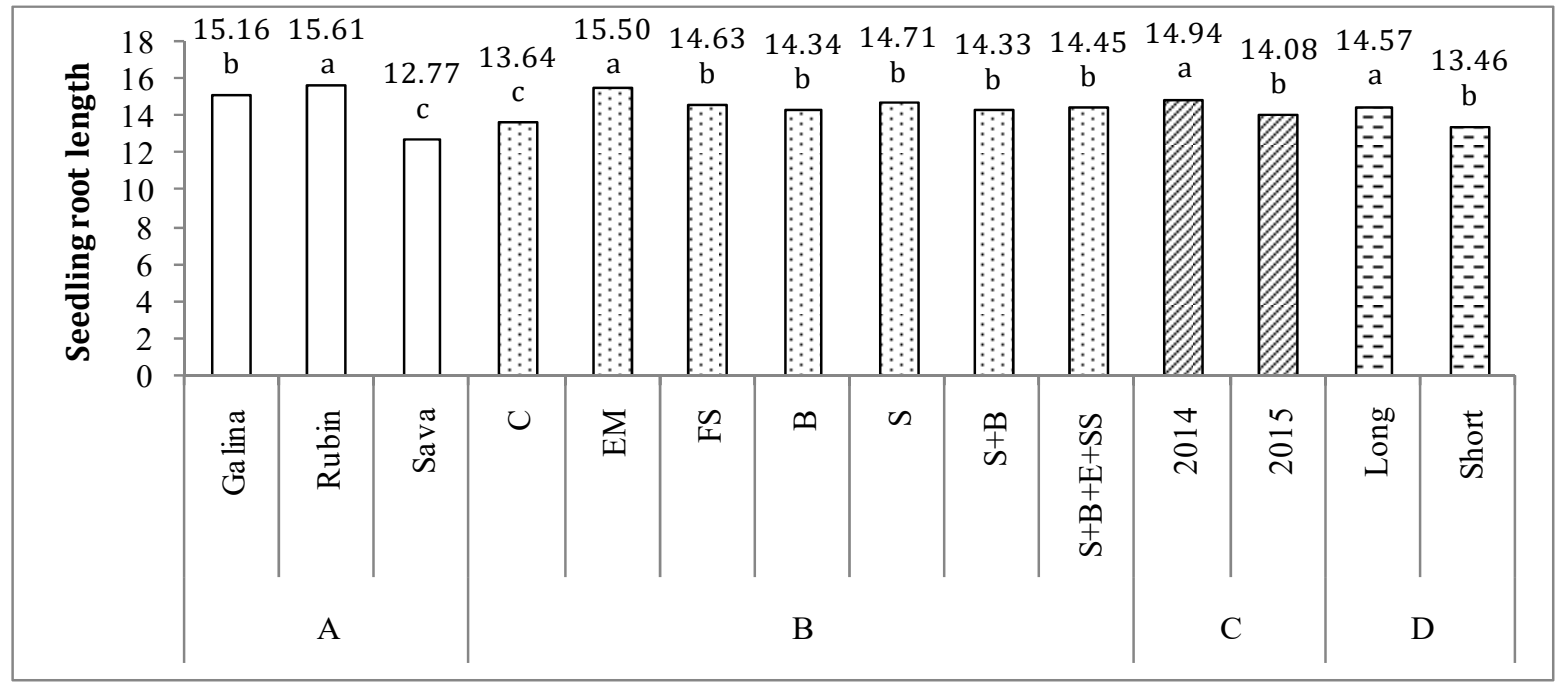

Figure 1. Influence of seed treatment on root length

The beneficial effect of Slavol S can be attributed to the active ingredient, which is indole-3-acetic acid. Indole-3-acetic acid is considered the most important natural auxin in higher plants. Auxins are phytohormones that affect plant growth by participating in stretching and cell division, inducing root growth (Normanly et al., 1995). Slavol S was also found to have a positive influence on sunflower seeds (Miladinov et al., 2014b; Miklić et al., 2016).

However, when combined with other biostimulants, its effect is reduced, and therefore the root is shorter than when treated with Slavol S alone, which is in agreement with the results conducted by Miladinov et al. (2015). Miladinov et al. (2014b) have also indicated that the effect of biostimulants is also significantly dependent on genotype, which is consistent with the research on soybeans. The results showed that the use of biostimulants had the greatest effect on root growth in 'Rubin'. 'Rubin' had a significantly longer root system than the other varieties. The root length of 'Rubin' was $15.61 \mathrm{~cm}$, which is $2.97 \%$ and $18.19 \%$ longer than that of 'Galina' and 'Sava', respectively. The rapid development of the root system is of great importance to the plant, especially under water deficit conditions during germination, because it allows plants to quickly reach soil moisture (Gupta et al., 2008). Using alonger strip of filter paper, a significantly higher root length $(14.57$ $\mathrm{cm}$ ) was observed, which is a $7.62 \%$ increase. This is understandable, because the root had no physical barriers, and could therefore unfold vertically downward, which is of great importance for the initial growth of the seedling.

\section{Effect of biostimulants on soybean seedling hypocotyl growth}

The biostimulants Slavol S, Terra Green Hobby and EM Aktiv significantly influenced hypocotyl growth. Compared with the control, Slavol S increased hypocotyl length by $8.24 \%$, Terra Green Hobby by 6.52 $\%$, and EM Aktiv by $4.97 \%$. By contrast, the combination of $\mathrm{S}+\mathrm{B}+\mathrm{E}+\mathrm{SS}$ reduced the length of the hypocotyl by $4.67 \%$ (Figure 2 ). 


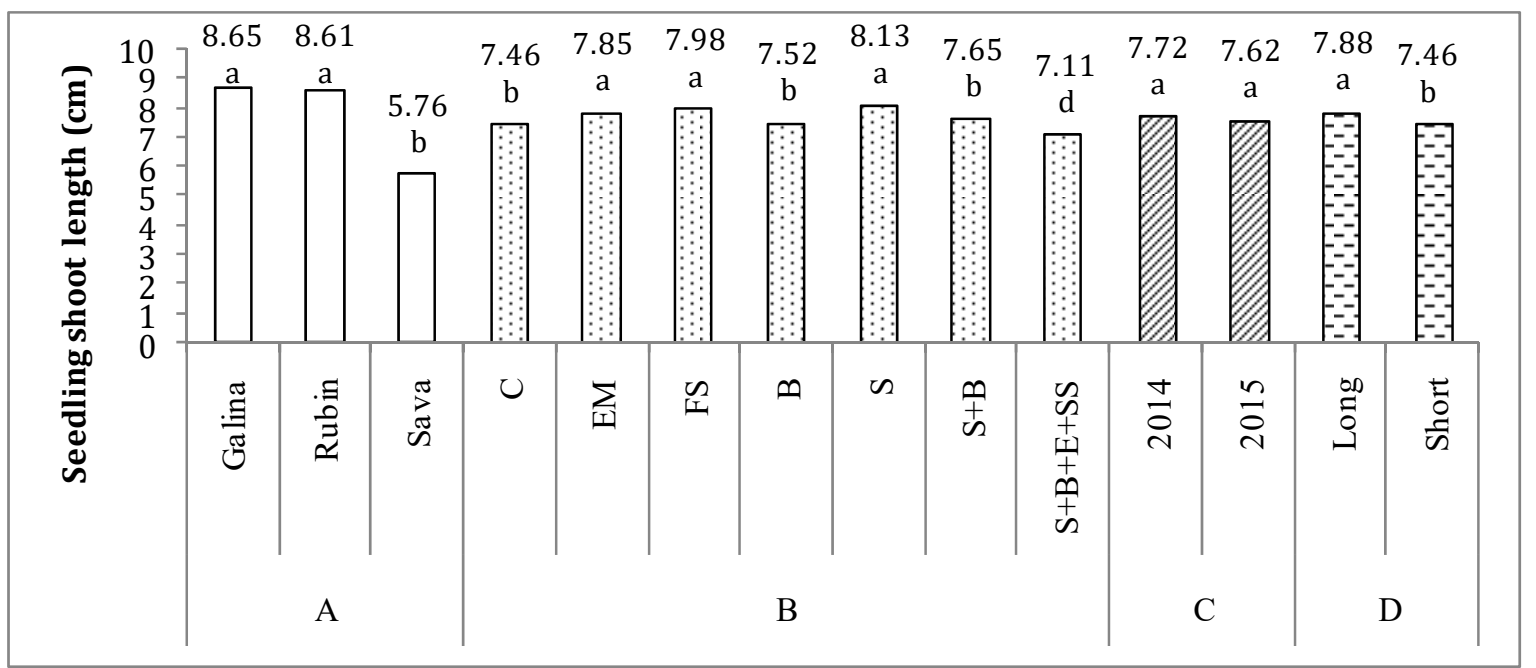

Figure 2. Influence of seed treatment on hypocotyl length

Similar results were reported on sunflower by Miladinov et al. (2014b). They found that the combined effect of Slavol S and Bioplant Flora resulted in an inhibitory effect on sunflower seedling hypocotyl, which was reduced by as much as $9.09 \%$ over control. Although many studies have indicated the positive effect of humic acids - the active substance of Bioplant Flora - on germination, plant growth and development (Russo and Berlyn, 1990; Parađiković, 2008; Zeljković, 2013), their effect on hypocotyl length has not been established. The results of the present study showed that the effect of biostimulants is significantly dependent on genotype, which is in line with the results on soybean (Cindrić, 2019) and sunflower (Miladinov et al., 2014b). The results showed that the use of biostimulants had a significantly better effect in 'Galina' and 'Rubin'. The hypocotyls of 'Galina' and 'Rubin' were, respectively, $33.41 \%$ and $33.10 \%$ longer than those of 'Sava'.

\section{Effect of biostimulant on soybean seedling weight}

As regards the influence of biostimulants on soybean seedling weight, Slavol $\mathrm{S}$ gave the greatest increase. In comparison with the control, seedling weight was increased by $5.15 \%$. The results are consistent with the research conducted by Jelacic et al. (2006). Kaludjerovic and Mirecki (2013) determined that Slavol S increased the weight of lettuce seedlings by an average of $35.74 \%$. The weight was increased regardless of the substrate used for seedling growth Bioplant Flora reduced seedling weight by $2.17 \%$ over control, which is statistically insignificant. However, the results contradict the research conducted by Türkmen et al. (2004) on tomatoes. They found that humic acid based products, such as Bioplant Flora, increased the content of macro and microelements, resulting in improved growth. However, a positive effect was only present when the product was used at certain concentrations. At high concentrations, its effect was negative. The combination of two biostimulants, $\mathrm{S}+\mathrm{B}$, did not have a significant effect on seedling weight relative to the control. However, the combination of three biostimulants, S + B + E + SS, gave a significantly lower seedling weight, compared with the control of $8.70 \%$ (Figure 3).

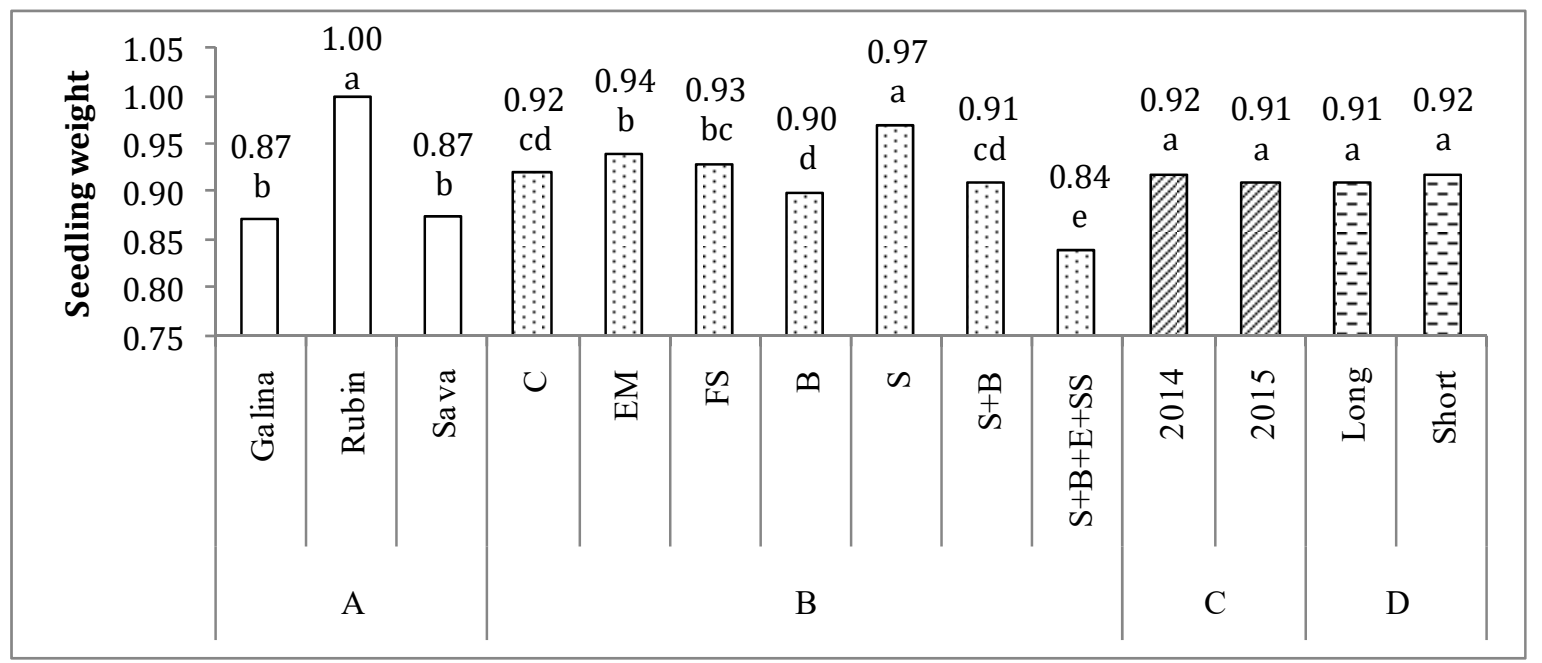

Figure 3. Influence of seed treatment on seedling weight 


\section{Correlation between tested parameters}

The application of Pearson's correlation coefficient revealed the highest positive correlation between hypocotyl length and seedling weight $\left(r=0.703^{* *}\right)$. The smallest positive correlation was found between root length and seedling weight $\left(r=0.314^{* *}\right)$, which is understandable, since most nutrients and water are taken up for building aboveground vegetative biomass and creating favorable conditions for the start of autotrophic feeding of a new young plant (Table 2).

Table 2.

Correlation between tested parameters

\begin{tabular}{|c|c|c|c|}
\hline Correlation & Seedling roots & Seedling hypocotyl & Seedling weight \\
\hline Seedling roots & 1 & $0.529^{* *}$ & $0.314^{* *}$ \\
\hline Seedling hypocotyl & $0.529^{* *}$ & 1 & $0.703^{* *}$ \\
\hline Seedling weight & $0.314^{* *}$ & $0.703^{* *}$ & 1 \\
\hline
\end{tabular}

\section{Conclusion}

Soybean varieties responded differently to biostimulant treatments. The most significant difference was found in the influence of biostimulants on root growth. The greatest effect was found in 'Rubin'.

Pre-sowing seed treatment with EM Aktiv showed the greatest effect on root growth. The root was on average $12 \%$ longer than the control.

Slavol S had the greatest influence on seedling hypocotyl and weight. The increase was $8.24 \%$ and $5.15 \%$, respectively, compared with the control.

The biostimulants were more effective on largesized filter paper, which was an expected finding because the seedling had no physical barriers and could develop smoothly.

The year of production had an effect only on root growth, whereas it did not have a significant effect on the other morphological parameters.

However, unlike the positive effects of certain biostimulants when used alone, their improper combination can inhibit the morphological properties of soybean.

\section{Acknowledgments}

This work is part of the research projects Ref. Nos. 451-03-68/2020-14/200378 and 451-03-68/2020$14 / 200009$, financed by the Ministry of Science and Environmental Protection of the Republic of Serbia.

\section{References}

Balesević-Tubić, S., Miladinović, J. (2014). Semenarstvo soje. Institut za ratarstvo i povrtarstvo, Novi Sad pp. 346.

Casenave, E.C., Toselli M.E. (2007). Hydro priming as a pretreatment for cotton germination under thermal and water stress conditions. Seed Science and Technology, 35, 88-98.

Cindrić, V. (2019). Fiziološka svojstva sjemena soje tretiranog regulatorom rasta i fungicidom. Diplomski rad, Fakultet agrobiotehničkih znanosti Osijek, pp. 34.

Cvijanović, M. (2017). Efekat niskofrekventnog elektromagnetnog polja i bioloških komponenti na prinos i kvalitet semena u održivoj proizvodnji soje. Doktorska disertacija, Poljoprivrednio fakultet, Zemun, pp. 247.

Djukić, V., Miladinov, Z., Dozet, G., Cvijanovic, M., Tatic, M., Miladinovic, J., Balesevic-Tubic, S. (2017). Pulsed electromagnetic field-a cultivation practice used to increase soybean seed germination and yield. Zemdirbyste-Agriculture 104 (4), 345-352.

Dozet, G., Cvijanović, G., Đukić, V., Cvijanović, D., Kostadinović Lj. (2014). Effect of microbial fertilizer on soybean yield in organic and conventional production. Turkish Journal of Agriculture and Natural Sciences, Special Issue 1, 13331339.

Food and agriculture organization of the United Nations (2013). FAOSTAT, Production, ProdSTAT, Crops. http://faostat.fao.org

Gajc-Wolska, J., Kowalczyk, K., Nowecka, M., Mazur, K., Metera, A. (2012). Effect of organic-mineral fertilizers on the yield and quality of Endive (Cichorium endivia L.). Acta Scientiarum Polonorum Hortorum Cultus, 11, 189-200.

Gupta, A., Dadlani, M., Arun Kumar, M. B., Roy, M., Naseem, M., Choudhary, V.K., Maiti R.K. (2008). Seed Priming: the aftermath. International Journal of Agriculture, Environment and Biotechnology, 1, 199-209.

Jelačić, S., Beatović, D., Vujošević, A., Lakić, N. (2006). Uticaj prirodnih biostimulatora i spororazlagajućih đubriva na kvalitet rasada bosiljka (Ocimum basilicum L.) i matičnjaka (Melissa officinnnnalis L.). Poljoprivredna tehnika, 4, 117-123.

Kaluđerović G., Mirecki N. (2013): Influence of applied agricultural measures on the seedling quality of lettuce. IV International Symposium "Agrosym 2013", Jahorina, Bosnia and Herzegovina, pp. 302-308.

Kolomaznik, K., Pecha, J., Friebrovà, V., Janàčovà, D., Vašek, V. (2012). Diffusion of biostimulators into plant tissues. Heat and Mass Transfer, 48, 1505-1512.

Miklič, V., Ovuka, J., Balalić, I., Hladni, N., Cvejić, S., Miladinov, Z., Jocić, S. (2016). Effect of biostimulators on seed quality, yield and oil content in sunflower. 19th International Sunflower Conference, Edirne, Turkey, pp. 948-957.

Miladinov, Z., Radić, V., Miklič, V., Crnobarac, J., Balalić, I., Jocković, M., Mrđa, J. (2014a). Uticaj biostimulatora na energiju klijanja i klijavost semena suncokreta. Ratarstvo i povrtarstvo, 51: 29-37.

Miladinov, Z., Radić, V., Balalić, I., Crnobarac, J., Jocković, M., Jokić, G., Miklič, V. (2014b). Uticaj biostimulatora na dužinu korena i nadzemnog dela ponika roditeljskih linija suncokreta. Journal on Processing and Energy in Agriculture, 1(5), 225-228.

Miladinov, Z., Balalić, I., Radić, V., Crnobarac, J., Jocković, M., Jokić, G., Miklič, V. (2015). Uticaj biostimulatora na klijanje i rani porast klijanca suncokreta. Journal of Agricultural Sciences, 60(1), 1-9.

Miladinov, Z., Maksimović, I., Balesević-Tubić, S., Djukić, V., Čanak, P., Miladinović ,J., Djordjević, V. (2019). Priming seed mitigates the effects of saline stress in soybean seedlings. Legume Research. DOI:10.18805/LR-469.

Milošević, M., Ćirović, M., Mihaljev, I., Dokić P. (1996). Opšte semenarstvo. Institut za ratarstvo i povrtarstvo.Novi Sad. (pp. 53-60)

Normanly, J., Slovin, J.P., Cohen J.D. (1995). Rethinking auxin biosynthesis and metabolism. Plant Physiology, 107,323329.

Palfi, M., Matotan, Z., Matotan, S. (2017). Utjecaj tretiranja sjemena stimulatorom klijanja Ekobooster 1 na početni rast i razvoj paprike. Sjemenarstvo, 30(1-2), 45-53.

Parađiković, N., Vinković, T., Radman, N. (2008). Utjecaj biostimulatora na klijavost sjemena cvjetnih vrsta. Sjemenarstvo, 25, 25-33. 
Russo, R.O., Berlyn, G.P. (1990). The use of organic biostimulants to help low input sustainable agriculture. Journal of Sustainable Agriculture, 1, 19-42.

Szymanski, N., Patterson, R.A. (2003). Effective microorganisms (EM) and wastewater systems in future directions for on-site systems: best management practice. In: Patterson R. A., Jones M. J. (eds) On-site'03 Conference, 348-355.

Tkalec, M., Vinković, T., Baličević, R., Parađiković, N. (2010). Uticaj biostimulatora na rast i razvoj paprike (Capsicum annuum L.). Acta agriculturae Serbica, 15: 83-88.

Türkmen, Ö., Dursun, A., Turan, M., Erdinç, C. (2004). Calcium and humic acid affect seed germination, growth, and nutrient content of tomato (Lycopersicon esculentum L.). seedlings in saline soil conditions. Acta Agriculturae Scandinavica, Section B, Soil and Plant Science, 54, 168174.
Vernieri, P., Borghesi, E., Tognoni, F., Serra, G., Ferrante, A., Piaggesi, A. (2006). Use of biostimulants for reducing nutrient solution concentration in floating system. International Society for Horticultural Science, 718, 477484.

Yakhin, O.I., Lubyanov A.A., Yakhin I.A., Brown P.H. (2017) Biostimulants in Plant Science: A Global Perspective. Frontiers in Plant Science, 7, 2049.

Yildirim, E., Dursun, A., Guvenc, I., Kumlay, M. (2007). The effects of different salt, biostimulant and temperature levels on seed germination of some vegetable species. Acta Horticulturae, 579, 249-253.

Zeljković, S. (2013). Primjena biostimulatora u proizvodnji begonije (Begonija semperflorens Link. et Otto) i kadifice (Tagetes patula L.). Doktorska disertacija. Poljoprivredni fakultet, Novi Sad pp. 124. 